ESAT- Screening van ASS op jonge leeftijd 


\section{ESAT- Screening van ASS op jonge leeftijd}

Praktische handleiding voor signalering, screening en diagnostiek

prof. dr. J. Buitelaar

drs. E. van Daalen

dr. C. Dietz

prof. dr. H. van Engeland

prof. dr. R.J. van der Gaag

drs. D. van Steijn

dr. S. Swinkels

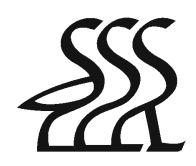

Bohn Stafleu van Loghum

Houten 2009 
(C) 2009 Bohn Stafleu van Loghum, onderdeel van Springer Uitgeverij

Alle rechten voorbehouden. Niets uit deze uitgave mag worden verveelvoudigd, opgeslagen in een geautomatiseerd gegevensbestand, of openbaar gemaakt, in enige vorm of op enige wijze, hetzij elektronisch, mechanisch, door fotokopieën of opnamen, hetzij op enige andere manier, zonder voorafgaande schriftelijke toestemming van de uitgever.

Voor zover het maken van kopieën uit deze uitgave is toegestaan op grond van artikel r6b Auteurswet $1912 \mathrm{j}^{\circ}$ het Besluit van 20 juni 1974, Stb. 35I, zoals gewijzigd bij het Besluit van 23 augustus 1985, Stb. 47I en artikel I7 Auteurswet I9I2, dient men de daarvoor wettelijk verschuldigde vergoedingen te voldoen aan de Stichting Reprorecht (Postbus 3051, 2130 KB Hoofddorp). Voor het overnemen van (een) gedeelte(n) uit deze uitgave in bloemlezingen, readers en andere compilatiewerken (artikel I6 Auteurswet I9I2) dient men zich tot de uitgever te wenden.

Samensteller(s) en uitgever zijn zich volledig bewust van hun taak een betrouwbare uitgave te verzorgen. Niettemin kunnen zij geen aansprakelijkheid aanvaarden voor drukfouten en andere onjuistheden die eventueel in deze uitgave voorkomen.

ISBN 9789031362400

NUR 776

Ontwerp omslag: Nanja Toebak, 's-Hertogenbosch

Ontwerp binnenwerk: Studio Bassa, Culemborg

Automatische opmaak: Pre Press, Zeist

Illustraties: Marcel Jurriëns

Bohn Stafleu van Loghum

Het Spoor 2

Postbus 246

3990 GA Houten

www.bsl.nl 
$\begin{array}{ll}\text { Voorwoord } & 7\end{array}$

I Inleiding 9

I.I Vroege herkenning van ASS 9

I.2 Praktische handleiding Io

2 Achtergrond $\quad$ I 2

2.I Inleiding I 2

2.2 Uitingsvormen op jonge leeftijd I5

2.2.I Sociale interactie I5

2.2.2 Communicatie 17

2.2.3 Rigiditeit en stereotypieën in gedrag en interesses 20

3 Signalering 23

3.I Wat is signaleren? 23

3.2 Praktisch instrument 25

3.2.I Gebruik van de Alarmsignalen 25

4 Screening 3 I

4.I Afname en scoring van de ESAT 32

4.2 Interpretatie van de resultaten 33

4.2.I Wat als ouders/verzorgers niet meewerken? 33

4.3 ESAT-items 34

$\begin{array}{lll}4.4 & \text { Videofragmenten } & 39\end{array}$

5 Diagnostiek 44

5.I Inleiding 44

5.2 Diagnostiek op jonge leeftijd 44

5.3 Hoe beoordeel je het gedrag van jonge
kinderen? 
5.4 De beoordeling van de verschillende stoornissen in het autistisch spectrum op jonge leeftijd

5.5 Diagnostisch onderzoek bij jonge kinderen

5.6 Het diagnostische traject

5.6.I Anamnestische gegevens over probleemgedrag

5.6.2 Anamnestische gegevens over zwangerschap, lichamelijke ontwikkeling, zintuiglijke ontwikkeling en lichamelijke gezondheid

5.6.3 Anamnestische gegevens over ouderlijk functioneren en opvoeding

5.6.4 Anamnestische gegevens over familieleden 56

5.6.5 Psychiatrisch onderzoek 56

$\begin{array}{lll}5.6 .6 & \text { Cognitief onderzoek } & 57\end{array}$

$\begin{array}{ll}5.6 .7 & \text { Lichamelijk onderzoek }\end{array}$

5.6.8 Diagnosestelling 59

5.6.9 Adviestraject 60

$\begin{array}{lll}5.7 & \text { Centra voor vroegdiagnostiek } & 60\end{array}$

Dankwoord 6 I

$\begin{array}{ll}\text { Over de auteurs } & 62\end{array}$

$\begin{array}{ll}\text { Literatuur } & 64\end{array}$

Bijlage I Schema Signalering $\quad 69$ 


\section{Voorwoord}

De ESAT- Screening van ASS op jonge leeftijd; een praktische handleiding over signalering, screening en diagnostiek is ontstaan uit een samenwerking tussen Karakter Universitair Cluster voor kinder- en jeugdpsychiatrie in Nijmegen en het Universitair Medisch Centrum Utrecht afdeling kinder- en jeugdpsychiatrie.

Aan de diverse onderdelen van deze uitgave werkten mee: drs. Karin Beuker, drs. Sharin Mercera, drs. Iris Oosterling, Kina Potze, drs. Sascha Roos, drs. Nele Schansman, drs. Saskia de Waal en drs. Tim Woudenberg.

De kinderen waren, op enkele kinderen na, allen betrokken bij het Diane-project van Karakter Universitair Cluster Locatie Nijmegen of het SOSO-project van het Universitair Medisch Centrum in Utrecht. Alle ouders hebben expliciet toestemming gegeven om het videomateriaal dat op de bijgevoegde dvd staat, te gebruiken voor educatieve doeleinden. Wij zijn hen én hun kinderen daarvoor erkentelijk. 